\title{
The Ethogram: Quantifying the Behavioral Picture and Justifying the Severity of Diseases
}

\author{
Motamed Elsayed Mahmoud* \\ Department of Animal Behavior, Sohag University, Egypt
}

Submission: July 19, 2017; Published: September 27, 2017

*Corresponding author: Motamed Elsayed Mahmoud, Department of Animal Behavior, Management, Genetics and Breeding, Faculty of Veterinary Medicine, Sohag University, Sohag, 82524, Egypt, Tel: +201065554590; Fax: +093457000; Email: motamed71111@gmail.com

\begin{abstract}
Ethnologists based their scientific study of animal behavior on ethogram. An ethogram is a quantitative description of animal behavior or the behavioral picture. Hence the basic information about animal behavior comes from observation. Furthermore, observation sheets lacking the ethogram has limitless boundary. Behavioral studies addressing a single question require designing a simple ethogram that refers to a number of behavioral signs each of them worth a digital value. In addition, ethological approaches for a specific behavioral pattern or disease necessitate customizing an ethogram. Therefore, watching the animal in home cage or natural habitat, taking careful notes, and making sense of the observed behaviors, writing down series of behavioral signs and organizing them in coherent fashion or in chronological order are the main procedure for preparing a customized ethogram. On other side, understanding animal body language and behavioral patterns that preserved or extinct from wild form is one of resources supplementing items of ethogram. Thusan integrated scientific research on animal behavior requires well prepared ethograms that not only include catalogue for the behavioral patterns but also their digital values according their appearance or absence in a prepared checklist. The fulfilled checklist describes a display of normal behavior or sickness behavior. Therefore lower the value of ethogram the higher is the deviation from normal or the reduction of disease severity.
\end{abstract}

Keywords: Ethogarm; Clinical behavior; Sickness behavior; Laboratory, Farm animals.

\section{Introduction}

Ethogram is an expression of behavior in an objective rather than subjective way [1,2]. The digital value for a prepared ethogram is considered acute edge for different forms of a specific disease (from per-acuteness to chronicity). This opinion is focusing on the necessity of preparing an ethogram for the behavior of animal and birds in health (e.g. comfort behaviors) and diseases [2]. We will emphasize the customized ethogram in experimentally-induced infected animal or natural diseases or affections. In addition, ethogram can be used in detection of different forms of abnormal behaviors such as stereo types [3].

Many reports referred to severaldiseasesthatcan bediagnosed by their behavioral picture e.g. Milk fever, Nymphomania [4]. We characterized the range of observed behaviors. The best way to generalize is to summarize the average of behaviors from many individual. So selecting small sized animals like laboratory mice will be helpful to observe a number of individuals. Here in we show in Table 1, an ethogram customized in chronically order for mice infected with Toxoplasma gondii $[5,6]$. In Table 2 we describe the severity of inflammation in terms of consistency and content of droppings in a chicken received an enema of trinitrobenzene of sulphonic acid [7]. In Table 3 display the behavioral picture due to unilateral or bilateral pressing of the horn on the head of rams and bucks [8].

Table 1: Ten check points each worth one for an ethogram in Balb/c mice infected with Toxoplasma gondii.

\begin{tabular}{|c|c|c|}
\hline 1 & Hunching & $01 /$ \\
\hline 2 & Piloerection & $01 /$ \\
\hline 3 & $\begin{array}{c}\text { Warmth-seeking behavior } \\
\text { (huddling/ burrowing bedding) }\end{array}$ & $01 /$ \\
\hline 4 & Sunken eye & $01 /$ \\
\hline 5 & Ptosis (dropping of upper eye lid) & $01 /$ \\
\hline 6 & Ataxia & $01 /$ \\
\hline 7 & Reluctant movement & $01 /$ \\
\hline 8 & $\begin{array}{c}\text { Deficient evacuation (defecation \& } \\
\text { urination) reflexes }\end{array}$ & $01 /$ \\
\hline 9 & Deficient touch reflexes & $01 /$ \\
\hline 10 & LOB (lying on belly) & $01 /$ \\
\hline
\end{tabular}


Table 2: Check points for this verity of colitis induced by trinitrobenze of sulphonic acid in chicken.

\begin{tabular}{|c|c|c|}
\hline \multicolumn{2}{|c|}{ Dropping consistency: } & Value $(\mathbf{0 , 2 , 4 )}$ \\
\hline 1 & Well-formed dropping & 0 \\
\hline 2 & Loose dropping & 2 \\
\hline 3 & Diarrhea & 4 \\
\hline \multicolumn{2}{|c|}{ Dropping with or without blood: } & Value (0, 2,4) \\
\hline 4 & No blood & 0 \\
\hline 5 & Occult of blood & 2 \\
\hline 6 & Gross Bleeding & 4 \\
\hline
\end{tabular}

Table 3: A customized ethogram displaying the signs in five check points due to unilateral or bilateral complication of horn over growths in sheep and goat.

\begin{tabular}{|c|c|c|}
\hline 1 & circling, head tilting & $01 /$ \\
\hline 2 & head or horn rubbing & $01 /$ \\
\hline 3 & head dropping & $01 /$ \\
\hline 4 & Bright/alert/dull/ & $01 /$ \\
\hline 5 & $\begin{array}{c}\text { apathetic/anxious/restless/ excitable/ and } \\
\text { manic }\end{array}$ & $01 /$ \\
\hline
\end{tabular}

\section{Conclusion}

Customizing ethograms for diseases based on clinical examination manuals for farm animals e.g. Infectious diseases in laboratory animals or for diseases models in laboratory animals (e.g. Diabetes, rheumatoid arthritis etc.) based on published articles and standard protocols, and laboratories manuals.

\section{Conflict of Interest}

The author declares that there is no conflict of interest.

\section{References}

1. Abeelen JHF (1964) Mouse mutants studied by means of ethological methods. Genetica 34(1): 95-101.

2. MacNulty D, Mech LD, Smith D (2007) A Proposed Ethogram of LargeCarnivore Predatory Behavior, Exemplified by the Wolf. Journal of Mammalogy 88(3): 595-605.

3. Mason GJ (1991) Stereotypes - A critical Review. Animal Behavior 41: 1015-1037.

4. Fraser AF, DM Broom (1990) Farm animal behavior and welfare. Wallingford, Oxon, UK; New York, USA: CAB International.

5. Dawkins MS (1989) Time budgets in red jungle fowl as a baseline for the assessment of welfare in domestic-fowl, Applied Animal Behavior Science 24: 77-80.

6. Mahmoud ME, Ihara F, Fereig RM, Nishimura M, Nishikawa Y (2016) Induction of depression-related behaviors by reactivation of chronic Toxoplasma gondii infection in mice. Behavioral Brain Research 298: 125-133.

7. Mahmoud ME, Hassanein K (2012) Prevention of tri-nitrobenzene of sulfonic acid- induced colitis by using extract of Aloe vera in chicken. World Veterinary Journal 5: 469-476.

8. El-Hawari SF, Elrashidy MH, Mahmoud ME (2015) Complications of horn overgrowth in sheep and goats with special reference to their clinical behavior and surgical management. Assiut Veterinary Medical Journal 61(146): 131-138.

Your next submission with Juniper Publishers
will reach you the below assets
- Quality Editorial service
- Swift Peer Review
- Reprints availability
- E-prints ServiceManuscript Podcast for convenient understanding
- Global attainment for your research
- Manuscript accessibility in different formats
( Pdf, E-pub, Full Text, Audio)
- Unceasing customer service
Track the below URL for one-step submission
https://juniperpublishers.com/online-submission.php

